\title{
Role of Oxidative Stress in $\mathrm{La}_{2} \mathrm{O}_{3}$
}

\section{Nanoparticle-Induced Cytotoxicity and Apoptosis in CHANG and HuH-7 Cells}

\author{
Hanouf Almukhlafi \\ Daoud Ali \\ Bader Almutairi \\ Khadijah $\mathrm{N}$ Yaseen \\ Nouf Alyami \\ Rafa Almeer \\ Saad Alkahtani (D) \\ Saud Alarifi
}

Department of Zoology, College of Science, King Saud University, Riyadh, Saudi Arabia
Correspondence: Saud Alarifi Department of Zoology, College of Science, King Saud University, BOX 2455, Riyadh, II45I, Saudi Arabia

Tel +966 I| 4679816

Fax +966 II 46785I4

Email salarifi@ksu.edu.sa
Introduction: Nanoparticles are extensively applied in pharmaceutical, agriculture, food processing industries, and in many other fields. In the current experiment, we have determined the mechanism of toxicity of lanthanum oxide nanoparticles $\left(\mathrm{La}_{2} \mathrm{O}_{3} \mathrm{NPs}\right)$ on human liver cell lines.

Methods: Before the investigation, we have characterized the size and shape of $\mathrm{La}_{2} \mathrm{O}_{3} \mathrm{NPs}$ using dynamic light scattering (DLS) and transmission electron microscope (TEM). The mean size of the $\mathrm{La}_{2} \mathrm{O}_{3} \mathrm{NPs}$ was found $32 \pm 1.6 \mathrm{~nm}$ with a sheet-like shape. The cytotoxicity effect of $\mathrm{La}_{2} \mathrm{O}_{3}$ NPs for $24 \mathrm{~h}$ on CHANG and HuH-7 cells was determined by using 3-(4,5-dimethylthiazol-2-yl)-2,5-diphenyltetrazolium bromide (MTT) and lactate dehydrogenase (LDH) assays.

Results: The cytotoxicity was observed in a concentration-dependent manner in both cells but NPs were more toxic to HuH-7 than CHANG cells. Generation of reactive oxygen species (ROS) was determined using fluorescent dye 2',7'-dichlorofluorescin diacetate (DCFDA) and high green fluorescence was observed in $\mathrm{HuH}-7$ cells than $\mathrm{CHANG}$ cells. Oxidative stress biomarker such as glutathione (GSH) was decreased and antioxidant enzyme superoxide dismutase (SOD) was increased but SOD level was decreased in HuH-7 cells than CHANG cells. Apoptotic cells were determined by using fluorescence-activated cell sorting (FACS) analysis. Maximum percentage of the apoptotic cell was observed at $300 \mu \mathrm{g} / \mathrm{mL}$ in $\mathrm{HuH}-7$ cells. DNA doublestranded breakage was observed by comet assay and maximum DNA damage was found in CHANG cells than HuH-7 cells at $300 \mu \mathrm{g} / \mathrm{mL} \mathrm{La2O3} \mathrm{NPs} \mathrm{for} 24 \mathrm{~h}$.

Conclusion: Thus, this study demonstrated that La2O3 NPs were toxic to human liver cells and induced more toxicity in HuH-7 cells than CHANG cells.

Keywords: $\mathrm{La}_{2} \mathrm{O}_{3}$ NPs, apoptosis, oxidative stress, CHANG and HuH-7 cells

\section{Introduction}

The big resource of rare earth metals is available in Asian countries such as Bangladesh, India, China, and Pakistan, etc. These rare earth metals reached into water bodies and the environment during smelting and mining as consequence pollution occurred. Nowadays various types of nanomaterials are manufactured using different nanotechnological techniques. In particular, rare earth elements such as lanthanum are extensively used in micro-fertilizers and micro-feeding in agriculture, animal husbandry, and aquaculture. ${ }^{1-3}$ Lanthanum was accumulated in the liver of normal and uremic rats. ${ }^{4}$ Lacour et al's ${ }^{5}$ exposure to lanthanum carbonate was accumulated in the body and induce potential liver toxicity. Production of ecofriendly 
nanomaterials is a big challenge a challenge that prepared nanotechnology one of the most studied and well-financed areas of the last decades. Metal nanomaterials are applied as base materials for cosmetics and skin care. Currently, rare earth metals are applied in animal husbandry, agriculture, the health industry. ${ }^{6}$ Due to the extensive application of rare earth metals in various areas, it gets into the environment, animals, and trophic levels, the human body. Chen et $\mathrm{al}^{7}$ had reported that chronic bioaccumulation of heavy metals or rare earth metals in the human body caused teratogenic and reproductive toxicity. Brabu et $\mathrm{al}^{8}$ have reported in vitro and in vivo biocompatibility of $\mathrm{La}_{2} \mathrm{O}_{3} \mathrm{NPs}$. Lanthanum chloride and samarium trinitrate decreased sperm counts, fertility, and increased deformity of sperm. ${ }^{9}$ Rare earth metals decreased superoxide dismutase, glutathione, and glutathione peroxidase and increased malondialdehyde levels and apoptotic activity during spermatogenesis. ${ }^{10}$ The generation of excess intracellular ROS induces toxicity in cells. Schumacker et $\mathrm{al}^{11}$ reported that due to excess ROS the dysfunction of mitochondria occurred. Production of ROS and apoptotic effect are the underlying mechanisms of toxicity of NPs. ${ }^{12}$ Zhuang et $\mathrm{al}^{13}$ reported that different enzymatic activities and induction of lipid peroxidation were observed in cells due to excessive ROS generation. Studies showed that oxidative stress is often associated with the induction of inflammation. To my knowledge, no studies confirmed the harmful effects of La2O3 NPs, on human liver cells. The objective of this study was to investigate the toxic effects of La2O3 NPs on human normal and cancer cells.

\section{Materials and Methods}

\section{Chemical and Reagents}

Lanthanum oxide $\left(\mathrm{La}_{2} \mathrm{O}_{3}\right)$ nanoparticles $\left(\mathrm{La}_{2} \mathrm{O}_{3} \mathrm{NPs}\right.$, 99.99\%, 10-100 nm, Stock\#: US3265) was purchased from US Research Inc. Houston TX USA. MTT, H2DCFH-DA), DMSO, and Annexin V FITC were bought from Sigma-Aldrich (St. Louis, Missouri, United States). DMEM and fetal bovine serum were purchased from Gibco, USA.

\section{Characterization of $\mathrm{La}_{2} \mathrm{O}_{3} \mathrm{NPs}$}

The La2O3NPs obtained were characterized using scanning electron/transmission electron microscope (SEM/ TEM) (JEOL Inc., Tokyo, Japan) operated at $200 \mathrm{kV}$ and X-ray diffraction (XRD) (Rigaku, Tokyo, Japan) operated at $9 \mathrm{~kW}$ and coupled with Smart Lab Guidance software (Smart Lab Studio II package software). Average hydrodynamic size and zeta potential of $\mathrm{La}_{2} \mathrm{O}_{3} \mathrm{NPs}$ in $\mathrm{dH}_{2} \mathrm{O}$ and culture medium were observed by DLS (NanoZeta Sizer-HT, Malvern, UK) as described. ${ }^{14}$ We have used $300 \mu \mathrm{g} / \mathrm{mL} \mathrm{La}_{2} \mathrm{O}_{3} \mathrm{NPs}$ suspension for DLS measurement and this is the maximum exposure concentration used to evaluate cell viability.

\section{Establishment of Cell Lines and Treatment of Nanoparticles}

CHANG and HuH-7 cells were procured from American Type Culture Collection (ATCC), USA. These cells were subcultured in DMEM with 10\% FBS and 10,000 U/mL antibiotics at a $5 \% \mathrm{CO}_{2}$ incubator at $37^{\circ} \mathrm{C}$.

CHANG and HuH-7 cells were sub-cultured overnight before exposure to La2O3NPs. The stock solution of $\mathrm{La}_{2} \mathrm{O}_{3}$ NPs was made in double-distilled water at the rate of $1 \mathrm{mg} \mathrm{La} 2 \mathrm{O} 3 \mathrm{NPs} / \mathrm{mL} \mathrm{DDW}$ and diluted according to the experimental dosage $(0-400 \mu \mathrm{g} / \mathrm{mL})$. Control cells were not exposed to NPs and were considered as controls with each experiment.

\section{Cell Viability Assay}

After 24 hrs incubation with $\mathrm{La}_{2} \mathrm{O}_{3} \mathrm{NPs}$ in $\mathrm{CHANG}$ and Huh-7 cells, mitochondrial activity was determined by the MTT test. ${ }^{15}$ MTT solution $(100 \mu \mathrm{L})$ was mixed to each well in a final concentration of $0.5 \mathrm{mg} / \mathrm{mL}$ and further left for incubation for an additional $3.5 \mathrm{~h}$. The resulted formazan was diluted in dimethyl sulfoxide (DMSO) and the absorbance was measured at $570 \mathrm{~nm}$ using BioTek Epoch plate reader (BioTek Instruments, Winooski, VT, USA) and Gen5 software (version 1.09).

\section{LDH Assay}

The lactate dehydrogenase (LDH) technique was followed as described. ${ }^{16}$ The cells were treated with different concentrations of $\mathrm{La}_{2} \mathrm{O}_{3} \mathrm{NPs}$ for one day. After treatment, the culture plate was centrifuged at $1200 \mathrm{rpm}$ for 10 minutes. Then supernantant $(100 \mu \mathrm{L})$ were taken from the culture plate. The LDH activity was examined in $1.0 \mathrm{~mL}$ of reaction mixture with $100 \mu \mathrm{L}$ of pyruvic acid $(2.5 \mathrm{mg} / \mathrm{mL}$ phosphate buffer) and $100 \mu \mathrm{L}$ of reduced nicotinamide adenine dinucleotide (NADH; $2.5 \mathrm{mg} / \mathrm{mL}$ phosphate buffer), and the rest of the volume was adjusted with phosphate buffer (0.1 mol/L, pH 7.4). The rate of NADH oxidation was determined by following the decrease in absorbance at $340 \mathrm{~nm}$ for 3 minutes at per minute intervals at $25^{\circ} \mathrm{C}$ using 
a spectrophotometer (Varian-Cary 300 Bio). The amount of LDH released is expressed as LDH activity (IU/L) in culture media.

\section{Investigation of $\mathrm{La}_{2} \mathrm{O}_{3} \mathrm{NPs}$ Uptake by CHANG and $\mathrm{HuH}-7$ Cells}

To investigate the ability of $\mathrm{La}_{2} \mathrm{O}_{3} \mathrm{NPs}$ penetration into the CHANG and HuH-7 cells over $24 \mathrm{~h}$ were analyzed by transmission electron microscopy (TEM). The cells $\left(3 \times 10^{4}\right)$ were seeded in a cell culture dish $(35 \mathrm{~mm})$ for $24 \mathrm{hrs}$. The suspension of La2O3 NPs was exposed for 24 hrs. Shang et al ${ }^{17}$ reported that uptake of nanoparticles was less at a higher concentration of nanoparticle exposure. So we selected a medium concentration $(100 \mu \mathrm{g} / \mathrm{mL})$ of $\mathrm{La} 2 \mathrm{O} 3 \mathrm{NPs}$ for the uptake test. CHANG and $\mathrm{HuH}-7$ cells were incubated with La2O3 NPs for $24 \mathrm{hrs}$ in the same environmental condition.

After exposure, we have fixed the cells in $2.7 \%$ glutaraldehyde for $60 \mathrm{~min}$ and sections of cells were prepared according to Cioriță et al. ${ }^{18}$ The sections were placed on copper grids and examined with TEM Jeol JEM 1010 (JEOL, Tokyo, Japan), operated at $80 \mathrm{kV}$, and coupled with a Mega View III digital camera. To confirm if the electron-dense accumulations seen inside cells were La2O3 NPs.

\section{Intracellular Reactive Oxygen Species (ROS) Generation}

The production of intracellular ROS in CHANG and $\mathrm{HuH}-$ 7 cells after exposure to La2O3 NPs $(0,10,20,50,100$, and $300 \mu \mathrm{g} / \mathrm{mL}$ ) for $24 \mathrm{hr}$ were measured as described. ${ }^{19}$

\section{Oxidative Stress}

After treatment with NPs for $24 \mathrm{hrs,}$, the cells were collected by $0.25 \%$ trypsin and crushed by ultrasonicator. After that, the cell lysate were used for the detection of the oxidative stress parameters like reduced glutathione (GSH), and superoxide (SOD) according to the following methods. Quantity of protein was determined using the method described by Bradford ${ }^{20}$ with BSA as the standard.

\section{GSH Level}

The GSH level was determined by using Alarifi et al method. ${ }^{21}$ The assay mixture contained phosphate buffer, 5, 5-dithiobis-(2-nitrobenzoic acid), and cell extract. The reaction was monitored at $412 \mathrm{~nm}$ and the amount of GSH was expressed in terms of GSH $\mathrm{mM} / \mathrm{mg}$ protein.

\section{SOD Level}

SOD test was done according to the method. ${ }^{21}$ The assay mixture contained $50 \mathrm{mM} \mathrm{Na}_{2} \mathrm{CO}_{3}, 1.6 \mathrm{mM}$ NBT, Triton $\mathrm{x}-100(10 \%)$ and $100 \mathrm{mM}$ of hydroxylamine- $\mathrm{HCl}$ along with the cell lysate was added and the optical density was determined at $560 \mathrm{~nm}$.

\section{Evaluation of Apoptotic and Necrotic Cells Using a Confocal Microscope}

Apoptotic and necrotic cells were detected by using $\mathrm{AO}$ and $\mathrm{EtBr}$ staining after exposure of $\mathrm{La} 2 \mathrm{O} 3 \mathrm{NPs}(0,10,20$, 50, 100, and $300 \mu \mathrm{g} / \mathrm{mL}$ ) in CHANG and HuH-7 cells after by using a confocal microscope (ZEISS LSM 900).

\section{AnnexinV-FITC}

After exposure of La2O3 NPs $(0,10,20,50,100$, and $300 \mu \mathrm{g}$ $\mathrm{mL}$ ) to CHANG and HuH-7 for $24 \mathrm{~h}$. The cells were washed with chilled PBS and collected in an Eppendorf tube and centrifuged at $1000 \mathrm{rpm}$ for 5 minutes. The cell pellets were mixed in binding buffer $(485 \mu \mathrm{L})$ with $5 \mu \mathrm{L}$ Annexin-V FITC and $10 \mu \mathrm{L}$ PI. The cell suspension was incubated at darkroom temperature for 30 minutes. After incubation, the cell suspension was detected by flow cytometry (Becton-Dickinson Immuno cytometry Systems, Sunnyvale, CA, USA). Fluorescence emitted by Annexin-V bound FITC and DNA-bound propidium iodide in each event was detected as red fluorescence, respectively. Results were analyzed by FACS Diva 6.1.2 software.

\section{Comet Assay}

DNA damage in CHANG and HuH-7 cells were determined using comet assay as described. ${ }^{22,23}$

\section{Statistical Analysis}

The data were analyzed by SPSS 26.0 software (IBM) and expressed as mean \pm standard error (SE). Statistical differences between the control group to exposed groups were determined by a one-way ANOVA test with the leastsignificant difference test. ${ }^{*}$ p-value $<0.05$ was considered statistically significant.

\section{Results}

\section{Characterization of La2O3 Nanoparticle}

$\mathrm{La}_{2} \mathrm{O}_{3} \mathrm{NPs}$ were purchased from US Research Nanomaterials Inc. (Houston, TX, USA) and have been characterized by SEM, TEM, XRD, and DLS methods. Nanoparticles were nonuniform sheet-like structures in shape and showing aggregation pattern as determined by TEM. Figure 1A and B showed the 
A

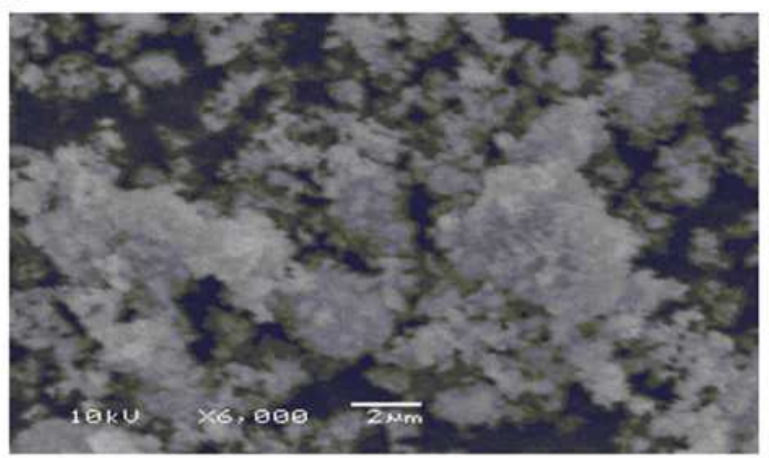

C

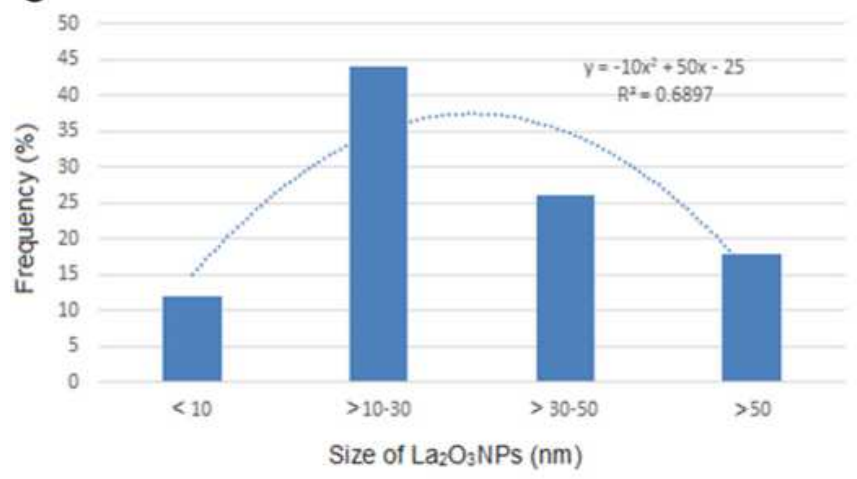

B

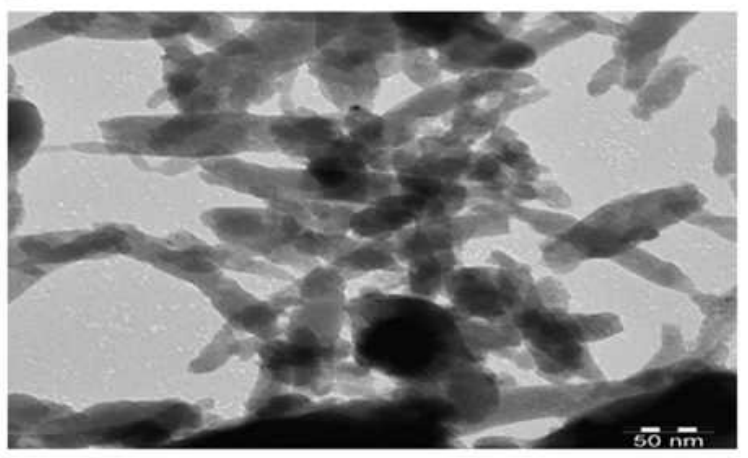

D

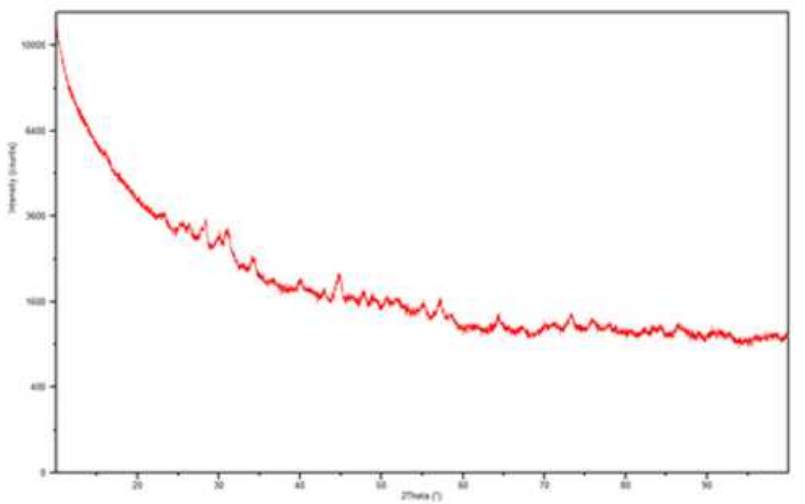

Figure I (A) SEM image of $\mathrm{La}_{2} \mathrm{O}_{3} \mathrm{NPs}$ (B). TEM image of $\mathrm{La}_{2} \mathrm{O}_{3} \mathrm{NPs}(\mathbf{C})$. Distribution of $\mathrm{La}_{2} \mathrm{O}_{3} \mathrm{NPs}_{\mathrm{s}}$ in water suspension (D). XRD spectrum of La $\mathrm{O}_{3} \mathrm{NPs}$.

images of La2O3 nanoparticles by SEM and TEM, respectively. The shape of La2O3NPs was a sheet-like structure (Figure 1A and B). The average size of NPs was $32 \pm 1.6 \mathrm{~nm}$ (Figure 1C). Figure 1D showed the spectrum of La2O3 NPs by XRD and it was shown $99.5 \%$ purity. After the suspension of La2O3 NPs in Milli Q water and DMEM, their size was determined using a Zetasizer, and size and zeta potential were $296 \pm 6.0 \mathrm{~nm}$ and $\sim 10.7 \pm 3.7 \mathrm{mV}$ and $161 \pm 9.9 \mathrm{~nm}$ and $\sim 11.5$ $\pm 4.9 \mathrm{mV}$ (Table 1 ).

\section{Uptake of La2O3 Nanoparticle in Cells}

We have observed the La2O3 NPs internalization in CHANG and HUH-7 cells was treated with $100 \mu \mathrm{g} / \mathrm{mL}$ for $24 \mathrm{hr}$, and untreated cells were used as control using TEM. $\mathrm{La}_{2} \mathrm{O}_{3}$ NPs have reached into the cell due to their smaller size ${ }^{24}$ and clusters of NPs were formed inside cells (Figure 2A-D).

\section{Cytotoxicity}

We have measured the cell viability of CHANG and HuH-7 cells after exposure to La2O3 NPs $(0,10,20,50,100$, and 300 $\mu \mathrm{g} / \mathrm{mL}$ ) for $24 \mathrm{hr}$. The result of cytotoxicity was shown in Figure $3 \mathrm{~A}$ and B. La2O3NPs induced cytotoxicity in CHANG and $\mathrm{HuH}-7$ cells in a dose-dependent manner. More toxic effect of La2O3 NPs was observed in CHANG cells than $\mathrm{HuH}-7$ cells at a higher dose of $300 \mu \mathrm{g} / \mathrm{mL}$ (Figure $3 \mathrm{~A}$ ).

The effect of La2O3 NPs on the plasma membrane of both cells was observed by using the LDH test. The leakage of LDH enzymes was increased as the concentration of NPs was increased. Thus it was confirmed that La2O3NPs deteriorated the membrane of cells and as a result apoptosis and cytotoxicity occurred (Figure 3B). The pattern of cytotoxicity in both cells showed an irregular pattern (Figure $3 \mathrm{~A}$ and $\mathrm{B}$ ).

Table I Physical Characterization of $\mathrm{La}_{2} \mathrm{O}_{3}$ Nanoparticles Using Dynamic Light Scattering. Data Represent the Mean \pm Standard Error $( \pm$ S.E) of Three Independent Experiments

\begin{tabular}{|l|l|l|l|}
\hline Nano Powder & Dispersant & DLS Mean \pm S.E. $(\mathbf{n m})$ & Zeta Potential \pm S.E. $(\mathbf{m V})$ \\
\hline $\mathrm{La}_{2} \mathrm{O}_{3}$ & Milli-Q-H $\mathrm{H}_{2}$ & $296 \pm 6$ & $\sim 10 \pm 3.7$ \\
& DMEM & $161 \pm 9.9$ & $\sim 11.5 \pm 4.9$ \\
\hline
\end{tabular}



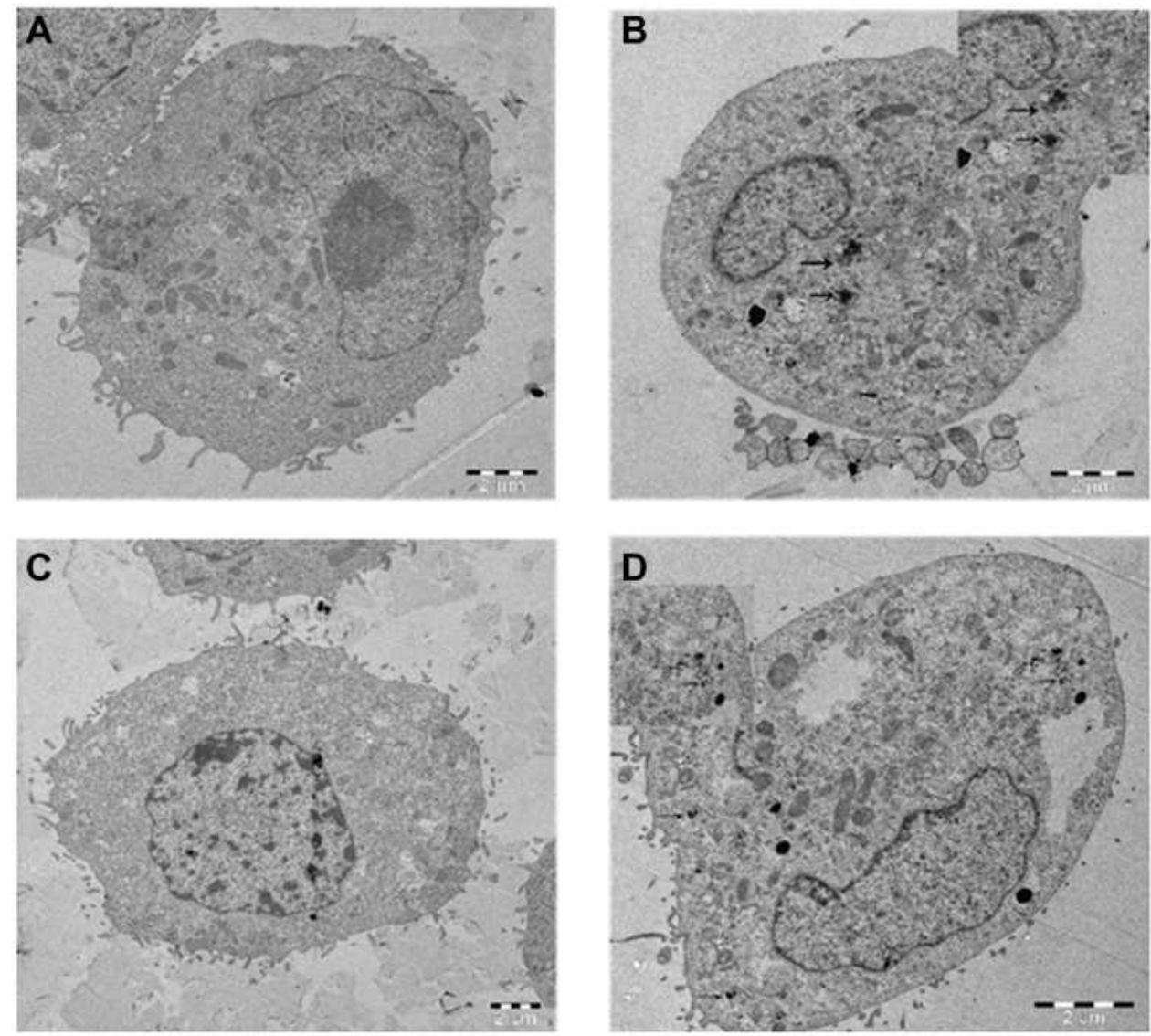

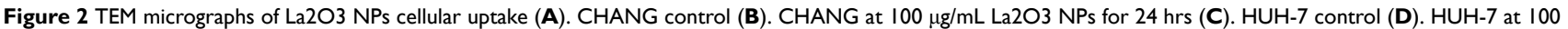
$\mu \mathrm{g} / \mathrm{mL}$ La2O3 NPs for 24 hrs. Black arrow = small NP aggregates.

\section{Oxidative Stress}

Oxidative stress was determined by measuring ROS, GSH and SOD enzymes in CHANG and HuH-7 cells. The formation of intracellular ROS was determined by capturing DCF fluorescence. The green fluorescence intensity was observed more at $100 \mu \mathrm{g} / \mathrm{mL}$ La2O3 NPs in CHANG cells (Figure 4A and E) than HuH-7 cells (Figure 4A and K). DCF fluorescence (green color) intensity was irregularly increasing and decreasing (Figure 4A-K). GSH and SOD were determined and statistically analyzed with control cells. The GSH level was decreased after exposing La2O3NPs and maximum declination was found in CHANG cells (Figure 5A) at 300 $\mu \mathrm{g} / \mathrm{mL}$ La2O3NPs. The level of SOD was increased irregularly in both cells (Figure 5B).

\section{Apoptosis}

The apoptotic and necrotic effects of NPs on CHANG and HuH-7 were evaluated by using FACS as a consequence we found $49 \%$ apoptotic cells in CHANG cells and 32\% apoptotic cells in $\mathrm{HuH}-7$ cells at $300 \mu \mathrm{g} / \mathrm{mL} \mathrm{La} 2 \mathrm{O} 3 \mathrm{NPs}$
(Figure 6K). We have observed the necrotic effect of NPs in CHANG cells at 100 and $300 \mu \mathrm{g} / \mathrm{mL} \mathrm{La2O3} \mathrm{NPs}$ (Figure 6K). We have presented in Figure 6A-J. The statistical analysis of early apoptotic and necrotic cells was determined by (FACS) as shown in Figure 6K.

Figure 7A and $\mathrm{B}$ showed apoptotic and necrotic cells in CHANG and HuH-7 by stained $\mathrm{AO} / \mathrm{EtBr}$, and images were captured by confocal microscope. The percentage of apoptotic and necrotic cells is shown in Figure $7 \mathrm{C}$ and maximum apoptotic cells were observed at $300 \mathrm{~g} / \mathrm{mL}$ in $\mathrm{HuH}-7$ cells (Figure 7C).

\section{DNA Damage}

DNA fragmentation in CHANG and $\mathrm{HuH}-7$ cells were observed (Figure 8A-K). DNA fragmentation was found in a dose-dependent manner in both cells. Maximum DNA damage was found in $\mathrm{HuH}-7$ cells at $300 \mu \mathrm{g} / \mathrm{mL} \mathrm{La} 2 \mathrm{O} 3$ NPs (Figure 8J and K). DNA damage occurred more in CHANG cells than HuH-7 cells at 20 and $50 \mu \mathrm{g} / \mathrm{mL}$ La2O3 NPs. DNA damage was slightly equal in both cells at $100 \mu \mathrm{g} / \mathrm{mL}$ La2O3 NPs (Figure 8D, I and K). 


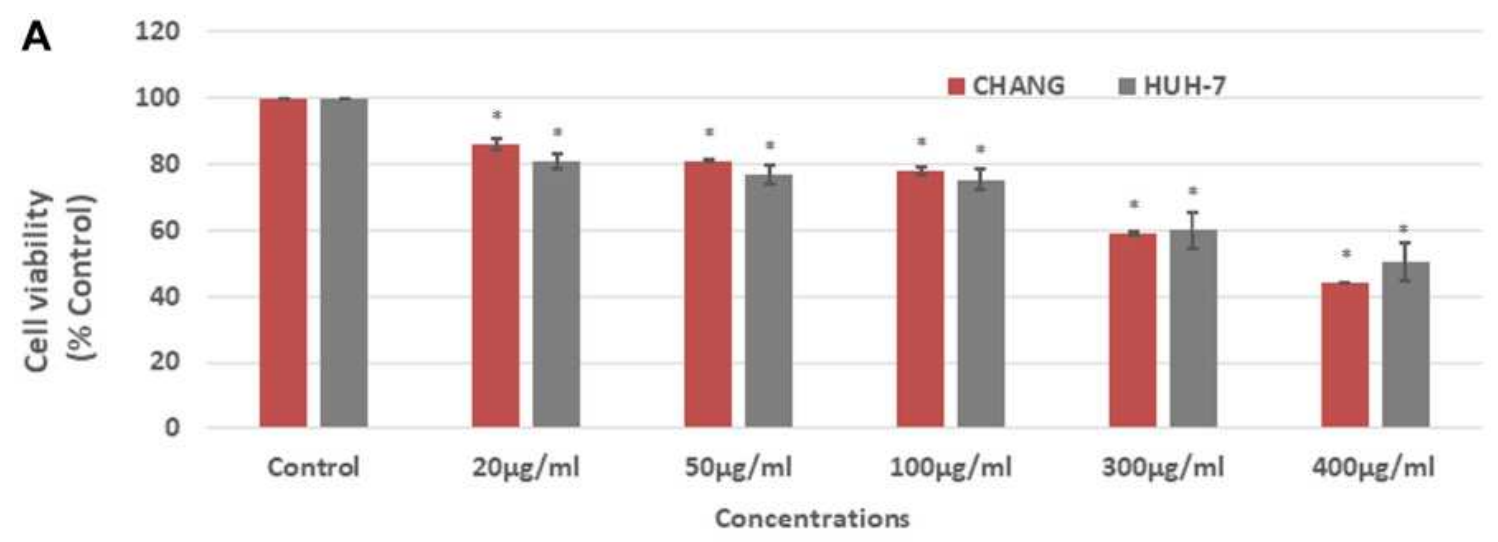

B

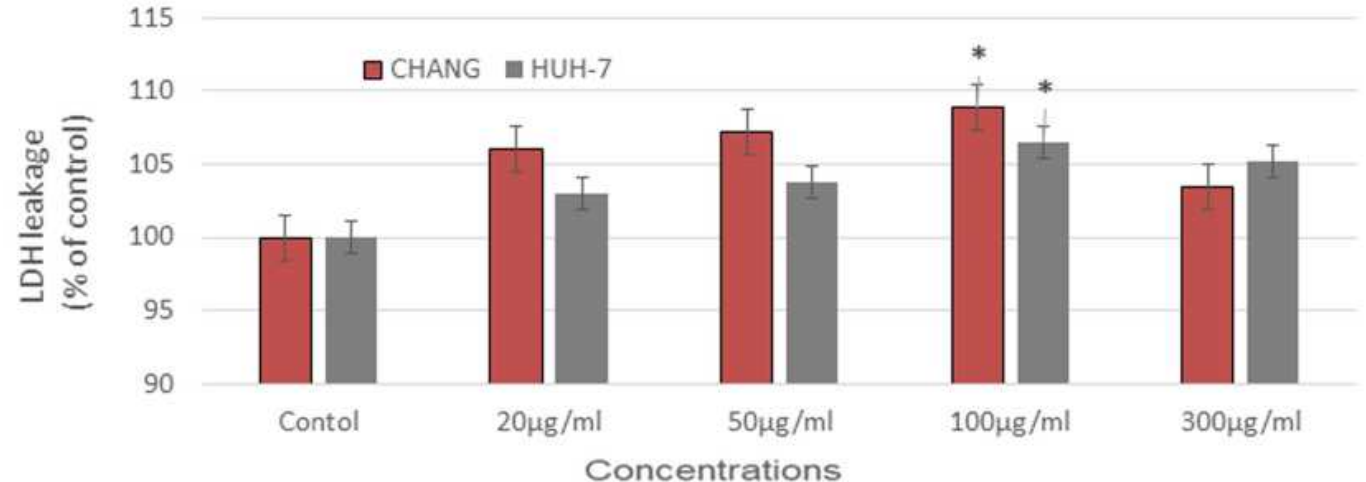

Figure 3 Cytotoxicity of $\mathrm{La}_{2} \mathrm{O}_{3} \mathrm{NPs}$ on CHANG and HuH-7 cells for 24 hrs, as evaluated by (A). MTT (B). LDH assays. Each value represents the mean \pm SE of three experiments. $n=3,{ }^{*} p<0.05$ vs control.
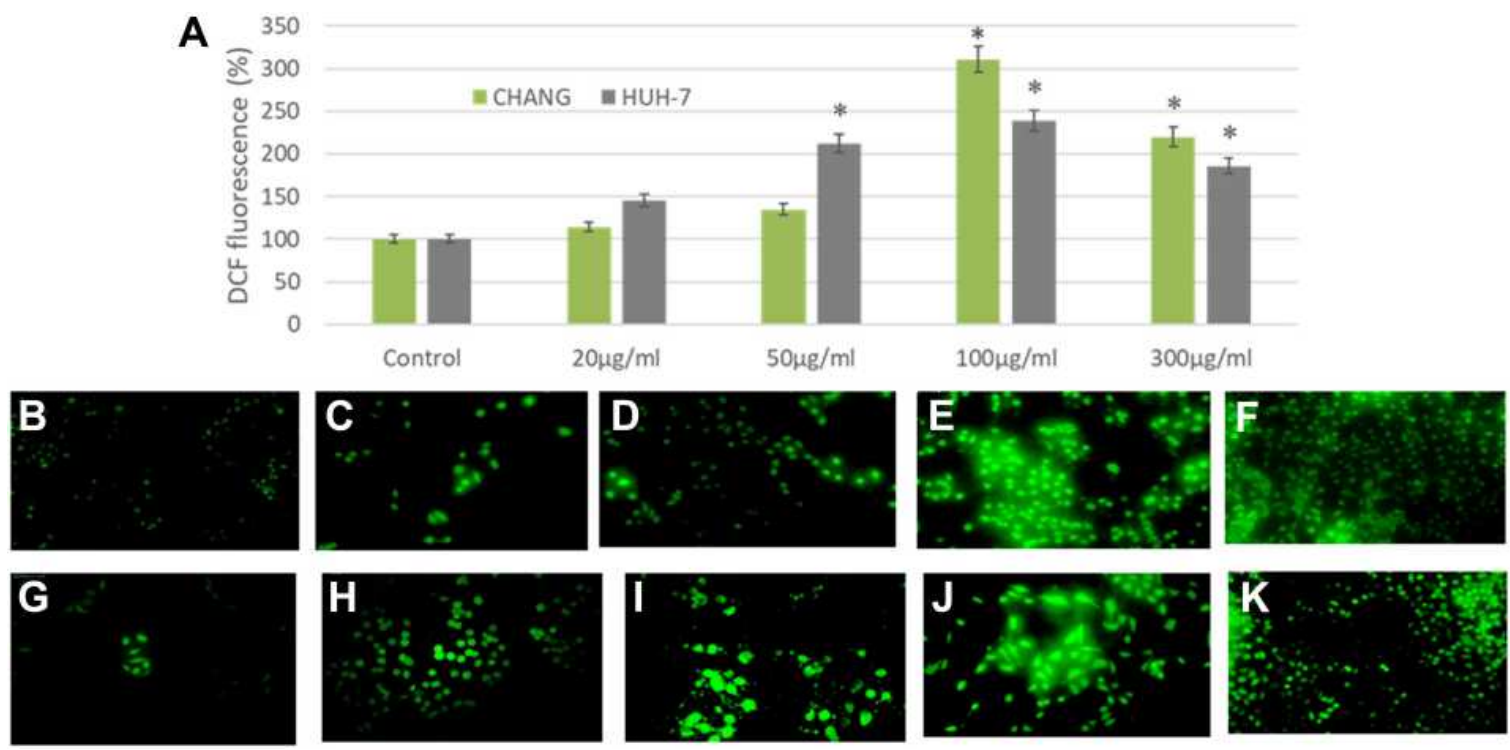

Figure 4 After exposure of La2O3NPs, production of intracellular ROS in CHANG and HuH-7 for 24 hrs (A). Percent of DCF fluorescence intensity and generation of green fluorescence in CHANG and HuH-7 for 24 hrs after exposure of La2O3NPs (B). Control CHANG cells (C). CHANG cells at $20 \mu g / \mathrm{mL}$ (D). CHANG cells at $50 \mu \mathrm{g} /$ $\mathrm{mL}$ (E). CHANG cells at $100 \mu \mathrm{g} / \mathrm{mL}$ (F). CHANG cells at $300 \mu \mathrm{g} / \mathrm{mL}$ (G). Control HuH-7 cells (H). HuH-7cells at $20 \mu \mathrm{g} / \mathrm{mL}$ (I). HuH-7cells at $50 \mu \mathrm{g} / \mathrm{mL}(\mathbf{J})$. HuH-7cells at $100 \mu \mathrm{g} / \mathrm{mL}(\mathbf{K})$. HuH-7cells at $300 \mu \mathrm{g} / \mathrm{mL}$. Each value represents the mean \pm SE of three experiments. ${ }^{*} p<0.05$ vs control. 


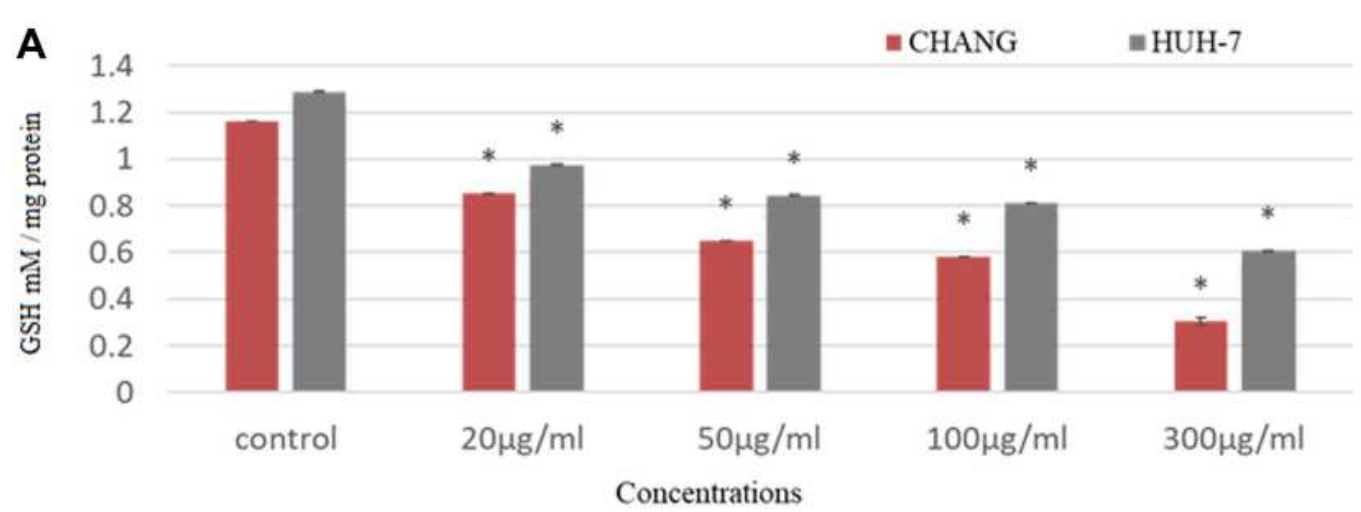

B

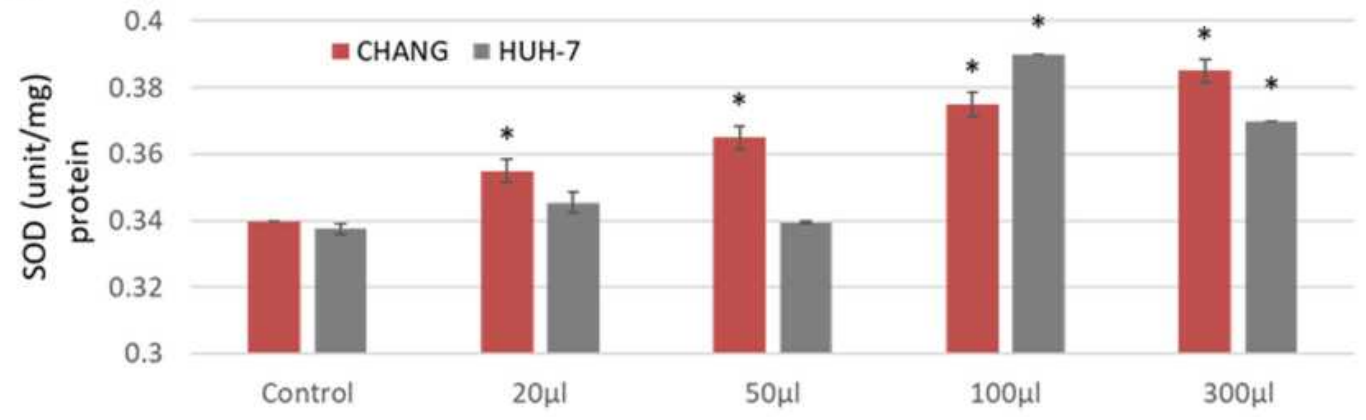

Figure 5 After exposure of La2O3NPs on CHANG and HuH-7 for 24 hrs (A). Levels of GSH (B). SOD in cells. Each value represents the mean \pm SE of three experiments. $*_{p}<0.05$ vs control.

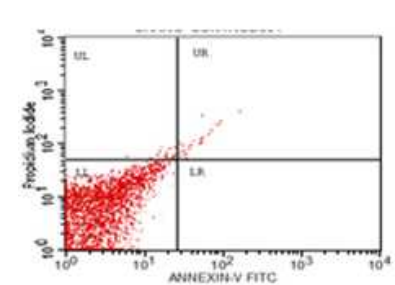

A

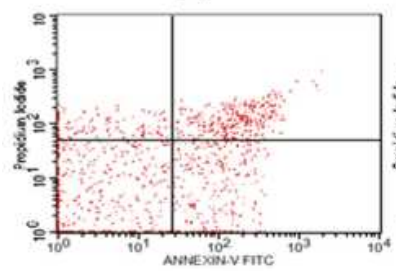

E

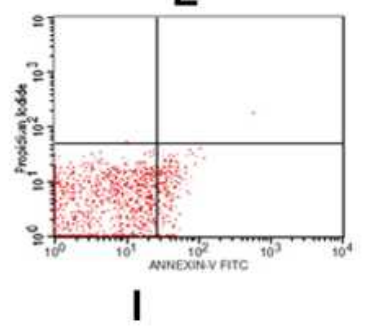

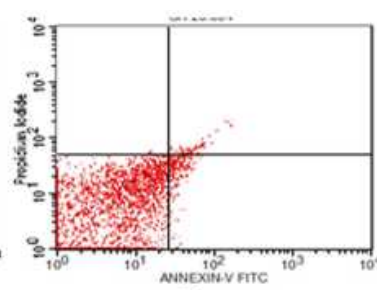

B

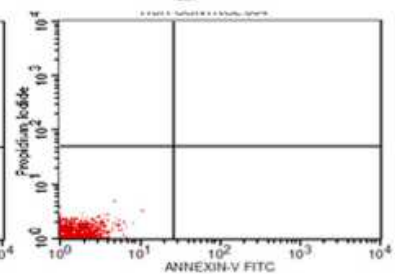

$\mathbf{F}$

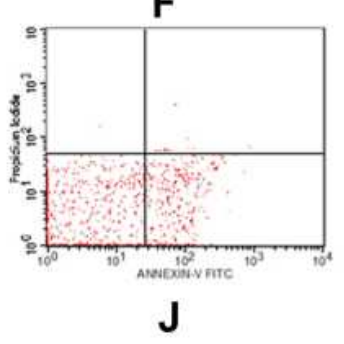

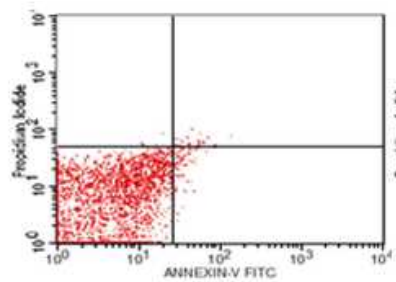

C

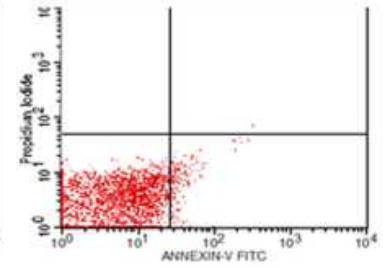

G

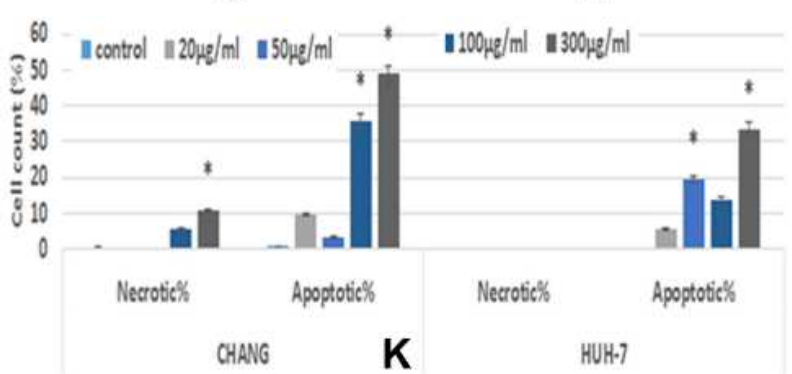

Figure 6 After exposure of La2O3NPs, scatter diagram of apoptotic and necrotic CHANG and HuH-7 for 24 hrs (A). Control CHANG cells (B). CHANG cells at $20 \mu$ g/ $\mathrm{mL}$ (C). CHANG cells at $50 \mu \mathrm{g} / \mathrm{mL}$ (D). CHANG cells at $100 \mu \mathrm{g} / \mathrm{mL}$ (E). CHANG cells at $300 \mu \mathrm{g} / \mathrm{mL}$ (F). Control HuH-7 cells (G). HuH-7cells at 20 $\mu \mathrm{g} / \mathrm{mL}$ (H). HuH-7cells at $50 \mu \mathrm{g} / \mathrm{mL}$ (I). HuH-7cells at $100 \mu \mathrm{g} / \mathrm{mL}(\mathbf{J})$. HuH-7cells at $300 \mu \mathrm{g} / \mathrm{mL}$. (K) Percent of apoptotic and necrotic CHANG and HuH-7 for 24 hrs after exposure of La2O3NPs. Each value represents the mean \pm SE of three experiments. ${ }^{*} p<0.05$ vs control. 

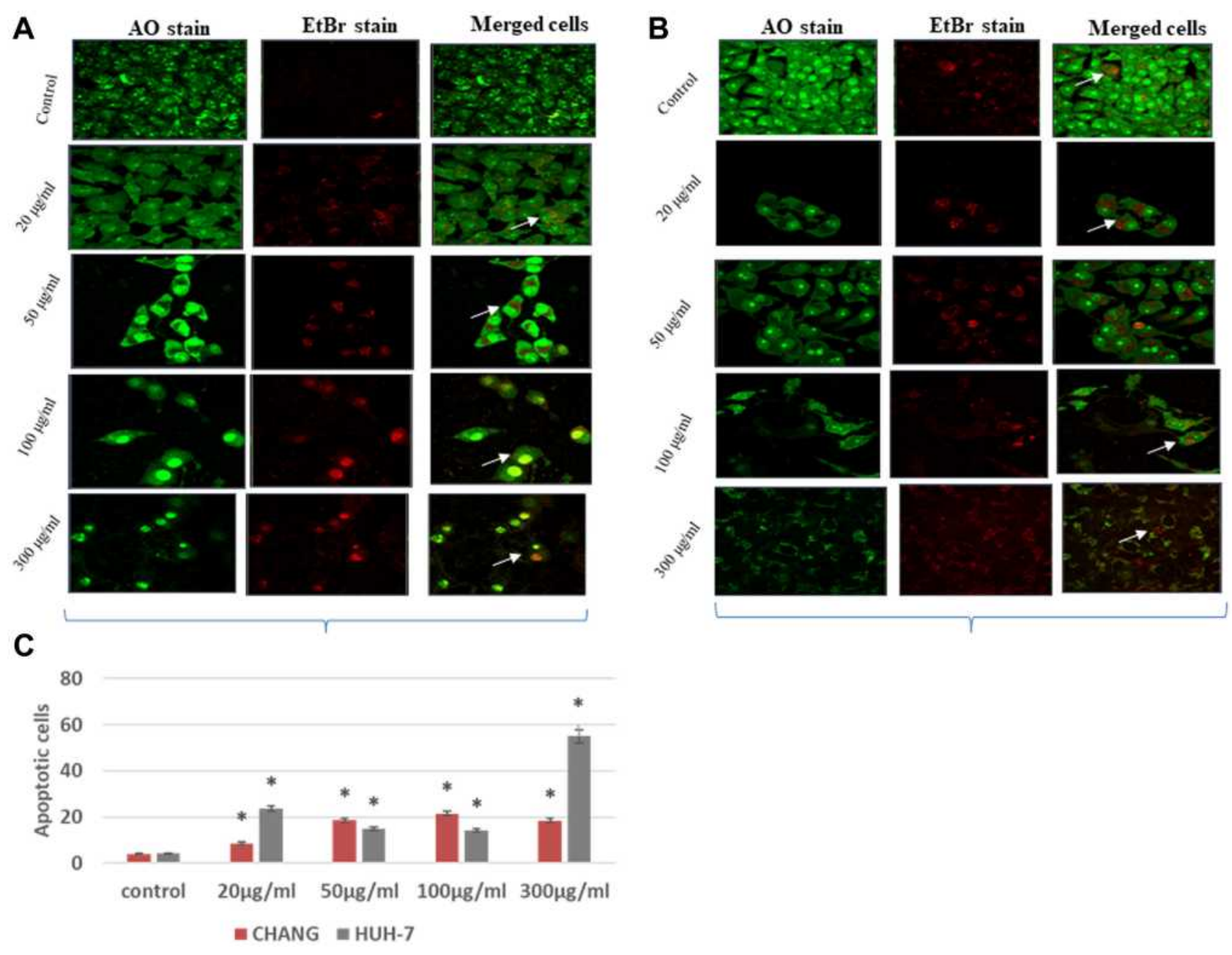

Figure 7 After exposure of La2O3NPs, induction of apoptotic and necrotic cells in CHANG and HuH-7 for 24 hrs (A). AO/Etbr staining fluorescence in CHANG cells for $24 \mathrm{hrs}$ after exposure of La2O3NPs (B). AO/Etbr staining fluorescence HuH-7 cells for $24 \mathrm{hrs}$ after exposure of La2O3NPs (C). Percent of apoptotic cells in CHANG and $\mathrm{HuH}-7$ cells after exposure of La2O3NPs for $24 \mathrm{hrs}$. Each value represents the mean \pm SE of three experiments. *p $<0.05$ vs control cells. Arrow indicates apoptotic cells.

Compared with the control group, DNA damage of La2O3 NPs was raised significantly $(p<0.05)$ in CHANG and HuH-7 cells (Figure 8A-K).

\section{Discussion}

Due to advanced technology, nowadays, nanomaterials are an important entity of our daily life and these have beneficial as well as harmful effects on human health. As the application of La2O3 NPs in daily use products has increased in the last few decades, which are unavoidable discharged into the natural environment. ${ }^{25}$ In this experiment, we have observed the toxic potential of La2O3 NPs on CHANG and HuH-7 cells. Before exposure of La2O3 NPs to cells, we have characterized the nature and size of nanoparticles using TEM, XRD, and Zetasizer. TEM analysis explored that the average size of NPs was $32 \mathrm{~nm}$ with a sheet-like structure shape (Figure 1A and B). In this study, ROS has a main role in inducing toxicity and apoptosis of CHANG and HuH-7 cells. We observed were bio distributed and internalized of toxicity La2O3 NPs in CHANG (Figure 2B) and HuH-7 cells (Figure 2C). Su et al ${ }^{26}$ reported that $\mathrm{La}^{3+}$ ions trigger apoptosis and in cancerous cells. We have observed the toxic effect of La2O3 NPs at all concentrations in both cells but maximum toxicity exerted in CHANG cells than $\mathrm{HuH}-7$ cells at $300 \mu \mathrm{g} / \mathrm{mL}$ for $24 \mathrm{~h}$. The current finding was corroborated with the finding of Sambale et $\mathrm{al}^{27}$ for the toxicity of silver nanoparticles in mammalian cell lines. Hence, La2O3 NPs exposure outcompeted in reduction viability and leakage of lactate dehydrogenase in CHANG and HuH-7 cells. Some researchers reported phytotoxicity of La2O3 NPs on Cucumis sativus L. ${ }^{28}$ In this experiment, we have investigated the generation of intracellular reactive 
A

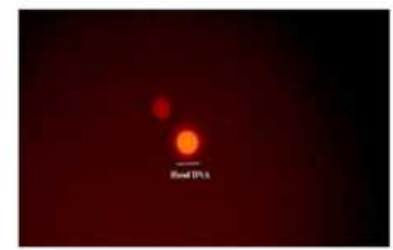

E

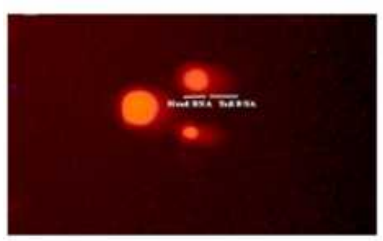

I

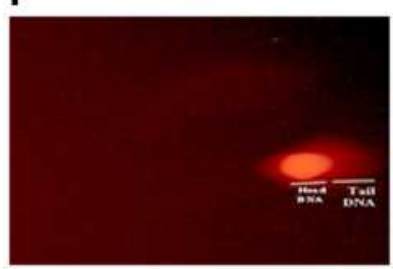

B

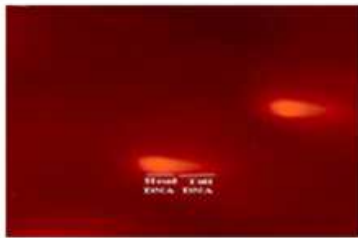

F

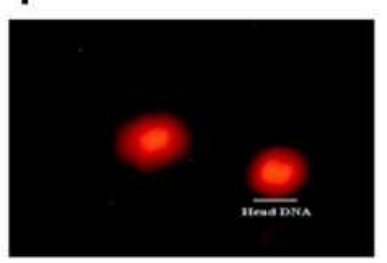

J

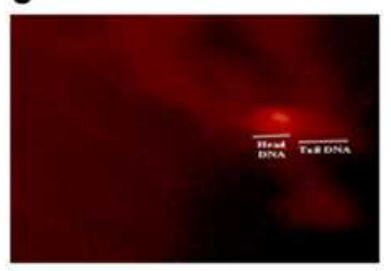

C

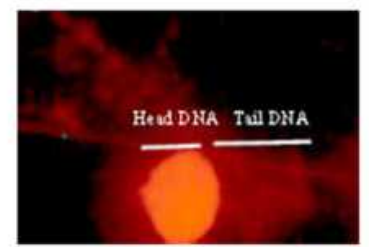

G

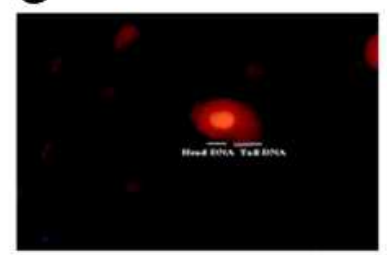

K

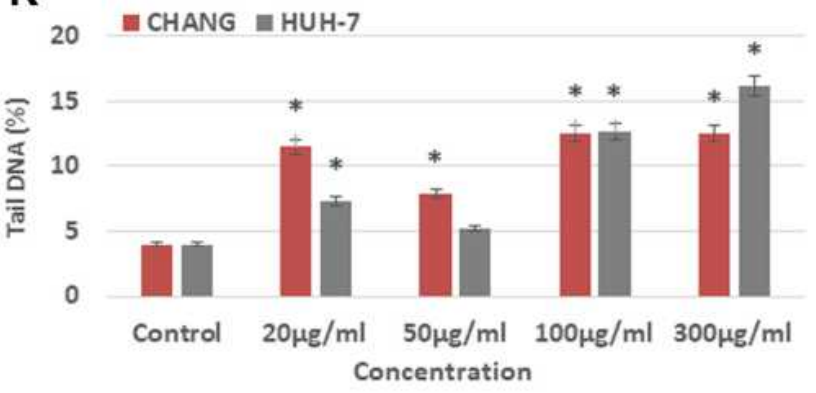

D

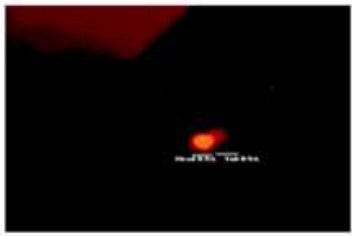

H

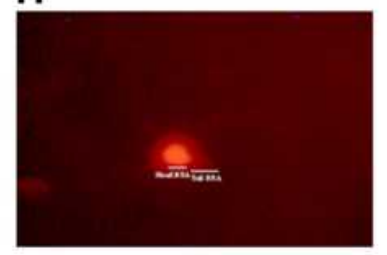

Figure 8 After exposure of La2O3NPs, DNA damage in CHANG and HuH-7 for $24 \mathrm{hrs}$ (A). Control CHANG cells (B). CHANG cells at $20 \mu g / \mathrm{mL}$ (C). CHANG cells at 50 $\mu \mathrm{g} / \mathrm{mL}$ (D). CHANG cells at $100 \mu \mathrm{g} / \mathrm{mL}$ (E). CHANG cells at $300 \mu \mathrm{g} / \mathrm{mL}$ (F). Control HuH-7 cells (G). HuH-7cells at $20 \mu \mathrm{g} / \mathrm{mL}$ (H). HuH-7cells at $50 \mu \mathrm{g} / \mathrm{mL}$ (I). HuH-7cells at $100 \mu \mathrm{g} / \mathrm{mL}(\mathbf{J})$. HuH-7cells at $300 \mu \mathrm{g} / \mathrm{mL}$. (K) Percent of tail DNA damage in CHANG and HuH-7 for 24 hrs after exposure of La2O3NPs. Each value represents the mean \pm SE of three experiments. ${ }^{*} p<0.05$ vs control.

oxygen species, and its generation was increased in a dosedependent manner and subsequently, production of ROS was higher in CHANG cell than $\mathrm{HuH}-7$ cells. The effect of ROS may be due to mitochondrial-mediated pathway as we found in our experiment. Victor et $\mathrm{al}^{29}$ reported that in the extrinsic pathway of apoptosis, still not approved ROS as an activator due to lanthanum NPs. Intrinsic pathway occurred in apoptosis due to nanoparticles. ${ }^{30} \mathrm{NP}$ produced free radicals which degenerate the cells through the generation of reactive oxygen species. We have confirmed the apoptotic response of La2O3 NPs using flow cytometry. Apoptotic and necrotic cells were induced at a higher concentration of NPs.

In conclusion, we have observed the toxic potential of La2O3 NPs depends upon the cell type of human liver cells. La2O3 NPs showed cytotoxicity, apoptosis, most likely due to its size effect and induction of ROS and oxidative stress. The most important finding from this study is that La2O3 NPs internalized passively into these liver cells and induced toxicity. Based on our findings, we observed HuH-7 cells are more sensitive to La2O3 NPs than CHANG cells. Further study of La2O3 NPs toxicity in vivo model in my further study.

\section{Acknowledgment}

The authors extend their appreciation to the Deanship of Scientific Research at King Saud University for funding this work through research group No (RG- 1441-180).

\section{Disclosure}

The authors report no conflicts of interest in this work.

\section{References}

1. Ning JB, Xiao SL. Effects of rare earth elements application on day lily. Chin Rare Earth. 1989;10(5):52-54.

2. Ni JZ. Bioinorganic Chemistry of Rare Earth Elements (In Chinese). Beijing: Science Press; 1995:450.

3. Tommasi F, Thomas PJ, Pagano G, Perono GA, Oral R, Lyons DM. Review of rare earth elements as fertilizers and feed additives: a knowledge gap analysis. Arch Environ Contam Toxicol. 2020. doi:10.1007/s00244-020-00773-4 
4. Slatopolsky E, Liapis H, Finch J. Progressive accumulation of lanthanum in the liver of normal and uremic rats. Kidney Int. 2005;68 (6):2809-2813. doi:10.1111/j.1523-1755.2005.00753.x

5. Lacour B, Nikolov IG, Joki N, Drüeke TB. Lanthanum carbonate, body lanthanum accumulation and potential liver toxicity. Nephrol Dial Transplant. 2007;22(6):1788-1789. doi:10.1093/ndt/gfm033

6. Blinova I, Muna M, Heinlaan M, Lukjanova A, Kahru A. Potential hazard of lanthanides and lanthanide-based nanoparticles to aquatic ecosystems: data gaps, challenges and future research needs derived from bibliometric analysis. Nanomaterials. 2020;10(2):328. doi:10.3390/nano10020328.

7. Chen J, Xiao H-J, Qi T, et al. Rare earths exposure and male infertility: the injury mechanism study of rare earths on male mice and human sperm. Environ Sci Pollut Res. 2015;22(3):2076-2086. doi:10.1007/s11356-014-3499-y

8. Brabu B, Haribabu S, Revathy M, et al. Biocompatibility studies on lanthanum oxide nanoparticles. Toxicol Res. 2015;4(4):1037-1044. doi:10.1039/C4TX00198B

9. Hu Z, Haneklaus S, Sparovek G, Schnug E. Rare earth elements in soils. Commun Soil Sci Plant. 2006;37(9-10):1381-1420. doi:10.1080/00103620600628680

10. Hua D, Wang J, Yu D, Liu J. Lanthanum exerts acute toxicity and histopathological changes in gill and liver tissue of rare minnow (Gobiocypris rarus). Ecotoxicology. 2017;26(9):1207-1215. doi:10.1007/s10646-017-1846-8

11. Schumacker PT, Gillespie MN, Nakahira K, et al. Mitochondria in lung biology and pathology: more than just a powerhouse. Am J Physiol Lung Cell Mol Physiol. 2014;306(11):L962-L74. doi:10.1152/ajplung.00073.2014

12. De Prins S, Dons E, Van Poppel M, et al. Surface plasmon resonance scattering and absorption of anti-EGFR antibody conjugated gold nanoparticles in cancer diagnostics: applications in oral cancer. Nano Lett. 2005;5(5):829-834. doi:10.1021/n1050074e

13. Zhuang C, Wang Y, Zhang Y, Xu N. Oxidative stress in osteoarthritis and antioxidant effect of polysaccharide from angelica sinensis. Int $J$ Biol Macromol. 2018;115:281-286. doi:10.1016/j. ijbiomac.2018.04.083

14. Alarifi S, Ali D, Alkahtani S. Oxidative stress-induced DNA damage by manganese dioxide nanoparticles in human neuronal cells. Biomed Res Int. 2017;2017:5478790. doi:10.1155/2017/5478790

15. Alarifi S, Ali D, Alkahtani S. Nanoalumina induces apoptosis by impairing antioxidant enzyme systems in human hepatocarcinoma cells. Int J Nanomedicine. 2015;10(1):3751-3760. doi:10.2147/IJN. S82050

16. Vanderlinde RE. Measurement of total lactate dehydrogenase activity. Ann Clin Lab Sci. 1985;15(1):13-31.

17. Shang L, Nienhaus K, Nienhaus GU. Engineered nanoparticles interacting with cells: size matters. J Nanobiotechnol. 2014;12(1):5. doi:10.1186/1477-3155-12-5
18. Ciorîtă A, Suciu M, Macavei S, et al. Green synthesis of Ag- $\mathrm{MnO}_{2}$ nanoparticles using Chelidonium majus and Vinca minor extracts and their in vitro cytotoxicity. Molecules. 2020;25(4):819. doi:10.3390/ molecules25040819

19. Alzahrani F, Khadijah M, Ali D, Alarifi S. Apoptotic and DNA-damaging effects of yttria- stabilized zirconia nanoparticles on human skin epithelial cells. Int $J$ Nanomedicine. 2019;14:7003-7016. doi:10.2147/IJN.S212255

20. Bradford MM. A rapid and sensitive method for the quantitation of microgram quantities of protein utilizing the principle of protein-dye binding. Anal Biochem. 1976;72(1-2):248-254. doi:10.1016/00032697(76)90527-3

21. Alarifi S, Ali D, Alkahtani S, et al. Induction of oxidative stress, DNA damage, and apoptosis in a malignant human skin melanoma cell line after exposure to zinc oxide nanoparticles. Int J Nanomed. 2013;8:983-993. doi:10.2147/IJN.S42028

22. Ali D, Nagpure NS, Kumar S, Kumar R, Kushwaha B. Genotoxicity assessment of acute exposure of chlorpyrifos to freshwater fish Channa punctatus (Bloch) using micronucleus assay and alkaline single-cell gel electrophoresis. Chemosphere. 2008;71 (10):1823-1831. doi:10.1016/j.chemosphere.2008.02.007

23. Ali D, Yadav PG, Kumar S, Ali H, Alarifi S, Harrath AH. Sensitivity of freshwater pulmonate snail Lymnaea luteola $\mathrm{L}$ to silver nanoparticles. Chemosphere. 2014;104:134-140.

24. Behzadi S, Serpooshan V, Tao W, et al. Cellular uptake of nanoparticles: journey inside the cell. Chem Soc Rev. 2017;46 (14):4218-4244. doi:10.1039/C6CS00636A

25. Liu Y, Xu L, Dai Y. Phytotoxic effects of lanthanum oxide nanoparticles on Maize (Zea mays L.). IOP Conf Ser Earth Environ Sci. 2018;113:012020. doi:10.1088/1755-1315/113/1/012020

26. Su X, Zheng X, Ni J. Lanthanum citrate induces anoikis of Hela cells. Cancer Lett. 2009;285(2):200-209. doi:10.1016/j.canlet.2009.05.018

27. Sambale F, Wagner S, Stahl F, Khaydarov RR, Scheper T, Bahnemann D. Investigations of the toxic effect of silver nanoparticles on mammalian cell lines. J Nanomater. 2015:9 pages. Article ID 136765.

28. Ma Y, He X, Zhang P, et al. Phytotoxicity and biotransformation of La2O3 nanoparticles in a terrestrial plant cucumber (Cucumis sativus). Nanotoxicology. 2011;5(4):743-753. doi:10.3109/ 17435390.2010 .545487

29. Victor ML, Toni RJ, Kerrie LM. Cytotoxic lanthanum oxide nanoparticles sensitize glioblastoma cells to radiation therapy and temozolomide: an in vitro rationale for translational studies. Sci Rep. 2020;10(1):18156. doi:10.1038/s41598-020-75372-3

30. Mkandawire MM, Lakatos M, Springer A, et al. Induction of apoptosis in human cancer cells by targeting mitochondria with gold nanoparticles. Nanoscale. 2015;7(24):10634-10640. doi:10.1039/ C5NR01483B
International Journal of Nanomedicine

\section{Publish your work in this journal}

The International Journal of Nanomedicine is an international, peerreviewed journal focusing on the application of nanotechnology in diagnostics, therapeutics, and drug delivery systems throughout the biomedical field. This journal is indexed on PubMed Central, MedLine, CAS, SciSearch ${ }^{\mathbb{R}}$, Current Contents ${ }^{\mathbb{R}} /$ Clinical Medicine, $^{2}$

\section{Dovepress}

Journal Citation Reports/Science Edition, EMBase, Scopus and the Elsevier Bibliographic databases. The manuscript management system is completely online and includes a very quick and fair peer-review system, which is all easy to use. Visit http://www.dovepress.com/ testimonials.php to read real quotes from published authors. 